\title{
Cartografías de lo real: de las nuevas subjetividades a las narrativas expandidas
}

\author{
Roberto Arnau Roselló \\ Universitat Jaume I \\ Arnau Gifreu Castells \\ Universitat de Girona
}

\section{Referencia de este artículo}

Arnau Roselló, Roberto, Gifreu Castells, Arnau (2020). Cartografías de lo real: de las nuevas subjetividades a las narrativas expandidas. En: adComunica. Revista Científica de Estrategias, Tendencias e Innovación en Comunicación, (19), 21-24. DOI: http://dx.doi.org/10.6035/2174-0992.2020.19.2.

El cine de lo real contemporáneo ha experimentado un auge en las últimas décadas que lo convierten en un punto de encuentro estilístico entre muy diversos discursos audiovisuales, géneros y propuestas formales. Las recientes aproximaciones a lo real, que combinan lo reflexivo con lo experimental, lo interactivo y lo hipertextual, generan un panorama plagado de heterodoxias formales y conceptuales, que amplían las fronteras del concepto y sirven de contrapunto en ese juego de influencias recíprocas en el que se ha convertido el género como respuesta a la complejidad del contexto multimodal en el que opera. Heredero de un concepto problemático, como el de documental, en el cine de lo real contemporáneo se produce un afinamiento de los dispositivos retóricos, una emergencia de diferentes voces y distintos relatos, hibridaciones discursivas y ampliaciones del género, que hacen tan necesaria como urgente una reflexión sobre el particular momento de desarrollo en el que se encuentra, sus derivas actuales y propuestas narrativas.

Por un lado, las nuevas subjetividades descansan sobre uno de los giros más radicales que ha vivido el documental a finales del siglo $\mathrm{XX}$, el giro subjetivo, a partir 
del cual el interés del documentalista se desplaza hacia el propio sujeto, hacia él mismo, en una búsqueda hacia la comprensión de las nuevas fenomenologías del yo. Por otro, el desarrollo de nuevos formatos o contenedores tecnológicos ha alumbrado nuevas formas hipertextuales de acercamiento a lo real que anuncian las expansiones que está experimentando la imagen documental y muestran su inusitada capacidad de desarrollo en el entorno digital. Se trata de un cine que demuestra explícitamente su carácter persuasivo, construido, subjetivo, que hace declaración de principios al desvelar sus propios mecanismos discursivos y al nutrirse del resto de discursos visuales con la libertad que otorgan los terrenos por explorar. Un cine que se imbrica con otras disciplinas y manifestaciones artísticas, que ha vivido una profunda transformación tanto en sus temáticas, como en sus formas, como en sus rutinas profesionales.

Este cine de lo real contemporáneo se ha convertido en un cine que rebasa los límites clásicos del documental tradicional, alumbrando nuevos procedimientos retóricos para sostener estas arquitecturas narrativas digitales. Las transformaciones e innovaciones afectan a múltiples elementos significantes fundamentales en la articulación del sentido y la narración documental como: los niveles de enunciación, la subjetividad del punto de vista, la relación autor-espectador, la quiebra de la transparencia como eje principal de la creación documental, la manipulación y tratamiento de las imágenes y el sonido digitales, el acercamiento a los personajes y el uso del testimonio, la interpelación a la memoria, la asimilación de una determinada iconografía, la superación y fragmentación posmoderna de los modos de representación, el uso y manipulación del archivo fílmico o audiovisual, la autobiografía, la intervención política, el terror documental, los cruces y sinergias entre realidad y ficción, la puesta en crisis de la representación y el desvelamiento de los mecanismos de manipulación visual, etc.

Así, con el objetivo fundamental de dotar de forma a un nutrido panorama, tan diverso como cuantioso, se incluyen en la sección Informe de este número 19 de la revista adComunica siete propuestas analíticas que dan cuenta de su heterogeneidad y abordan, desde perspectivas tan diferentes como complementarias, algunos de los aspectos fundamentales de la transformación del género durante esta última década.

En el primero de los artículos, Gabri Ródenas analiza la evolución y uso del término «verdad», en relación con «lo real», y cómo ha ejercido una fuerte influencia en la configuración del espacio público, especialmente debido a su poderosa dimensión mediática. Su objetivo consiste en estudiar términos como posverdad, poscensura y oclocracia, a través de una metodología híbrida que combina una aproximación teórica, con el análisis audiovisual. En este marco, el autor defiende la necesidad de establecer modelos de verificación de la información que palien los efectos perniciosos de la desinformación. Sus resultados se manifiestan en una propuesta de dos soluciones principales: la primera es la necesidad de una alfabetización me- 
diática global y la segunda el fomento del pensamiento crítico como filtro que evite la aceptación y propagación de ideas potencialmente dañinas para la convivencia (discursos de odio, racismo, xenofobia, homofobia, etc.).

Por otra parte, Sergio José Aguilar Alcalá, en un intento de superar la posición común que concibe el falso documental como un «tercer espacio» que habita entre la ficción y la no ficción, e hibrida ambos campos, propone retomar el concepto de «punto de vista» de los estudios fílmicos para entender la capacidad agencial de la forma cinematográfica para crear una experiencia de verdad ficcional. Tomando como base la distinción entre enunciado y enunciación, el autor considera que el falso documental abre un nuevo espacio que escapa a la lógica de la dicotomía ficción/no ficción, y con ello, puede decir la verdad mientras miente.

En el tercer artículo, Jorge Vázquez-Herrero presenta un estudio Delphi realizado con creadores, productores y responsables de innovación y área digital de medios de comunicación, que permite identificar las principales tendencias en la evolución de formatos como el documental interactivo. El autor propone un mayor conocimiento de las audiencias y la adaptación a las tecnologías influyentes, principalmente el desarrollo de la Web y el móvil, que articule el futuro de unas formas de expresión que son hegemónicas. Los resultados apuntan hacia que la no ficción interactiva posee interesantes potencialidades expresivas para la renovación narrativa, vinculadas con la interactividad y la inmersión.

La cuarta propuesta, presentada por Carlos Bria Lahoz y Sue Aran-Ramspott, propone una aproximación, desde el análisis fílmico y temático, a la trayectoria de uno de los cineastas más singulares y desconocidos de la cultura española contemporánea y a su vez precursor de muchas de las nuevas subjetividades del cine de lo real, el documentalista valenciano Llorenç Soler. El análisis se efectúa en torno a tres ejes temáticos principales: el compromiso con la alteridad, la militancia político social, y el eje cultural artístico.

La propuesta de Iván Pinto Veas y de María Paz Peirano Olate, por su parte, versa sobre las transformaciones epistémicas y estéticas del documental chileno entre los años 2000 y 2018, proponiendo una serie de reflexiones vinculadas a la función representacional del cine documental contemporáneo chileno, que según el autor habría pasado de la analogía y el registro hacia distintos tipos de búsquedas del dispositivo cinematográfico.

Alfredo Dillon nos presenta a continuación un artículo donde realiza un análisis en profundidad de las películas argentinas Gilda, no me arrepiento de este amor (2016) y El Potro, lo mejor del amor (2018). El estudio de estos dos biopics musicales permiten al autor aproximarse al auge reciente del género biográfico en el campo audiovisual. En esta propuesta, ese presenta una aproximación al concepto de «retorno de lo real», que implica un interés creciente por las narraciones en las que las fronteras entre ficción y realidad se desdibujan generando un tipo de 
ficción híbrida que oscila entre la veracidad y la invención, y en la que el espectador se ve inmerso en un estado de incertidumbre en relación con el estatuto de los hechos narrados.

La última aportación de esta sección, de Alejandro Alfredo Rafael Silva Fernández, nos acerca a las parentalidades lesbianas y gays en producciones documentales argentinas estrenadas después de la aprobación de la Ley de Matrimonio Igualitario. El autor, a partir de elementos de la semiótica del cine y el análisis textual, analiza específicamente los capítulos Familias diversas, Matrimonio Igualitario y Diversidad en el barrio de la serie documental Salida de Emergencia (2011) de Mathieu Orcel y La maternidad de Caleidoscopio: Diversos colores, los mismos derechos (2011) de María Victoria Glazmann.

Conjuntamente, estas siete aportaciones nos permiten acercarnos a las derivas contemporáneas del cine de lo real y comprender cómo los nuevos formatos están transformando por completo el universo audiovisual en la era digital.

La sección Tribuna, a su vez, presenta cuatro trabajos que dialogan entre ellos, complementando las aproximaciones que unos y otros contienen. La inclusión en esta sección del trabajo de Diego Zavala es excepcional y se debe al hecho de que su propuesta establece un diálogo muy fértil con el resto de artículos de la sección: con el artículo de Aarón Rodríguez en el que reflexiona sobre los retos de futuro a los que se enfrenta el ámbito específico de los Estudios Fílmicos, con el de Pablo Martín Zárate sobre el cine documental y el exceso de realidad en el que se funda su gesto enunciativo, y, por último, con el de Jacobo Sucari sobre cómo la participación ciudadana altera los procesos de construcción de sentido en el documental social participativo. 